\title{
BEHAVING OF PRIMARY SCHOOL PUPILS DURING SOLVING THE TASKS WITH A ROBOTIC KIT
}

Jan BAŤKO* , Západočeská univerzita v Plzni, Česká republika

Filip FRANK, Západočeská univerzita v Plzni, Česká republika

Lucie ROHLÍKOVÁ, Západočeská univerzita v Plzni, Česká republika

Prijiato: 7. 12. 2020 / Akceptováno: 13. 7. 2021

Typ článku: Výzkumná studie

DOI: 10.5507/jtie.2021.007

\begin{abstract}
The aim of our research was to find out how primary school pupils behave during solving the tasks in educational robotics. These tasks include the elements of abstraction which difficulty during the solving increases. A specific set of fifteen tasks, focused on the movement of a mobile robot in space, was created. The testing was done in two classes in the sixth year of primary school. In this article there is only a part of the results gained with direct observation and analysis of video records presented. The process of pupil adaptation on working in programming environment LEGO Mindstorms EV3 without prior knowledge of programming including gender differences and the most frequent mistakes is described here.
\end{abstract}

Key words: robotics, robotic kit, primary school, algorithms, programming, LEGO Mindstorms EV3.

\section{CHOVÁNÍ ŽÁKŮ ZÁKLADNÍ ŠKOLY PŘI ŘEŠENÍ ÚLOH S ROBOTICKOU STAVEBNICÍ}

Abstrakt: Cílem našeho výzkumu bylo zjistit, jak si žáci základní školy počínají při řešení úloh ze školní robotiky, které zahrnují prvky abstrakce a jejichž obtížnost v průběhu řešení stoupá. Vytvořena byla specifická sada patnácti testovacích úloh zaměřených na pohyb pojízdného robota v prostoru. Testování bylo provedeno ve dvou třídách žáků 6. ročníku základní školy. $V$ příspěvku je prezentována pouze část výsledků získaných př́mým pozorováním a analýzou videozáznamů. Je zde popsán proces adaptace žáků na práci v programovacím prostředí LEGO Mindstorms EV3 bez předchozích znalostí programování včetně genderových rozdílů a nejčastějších chyb. 
Klíčová slova: robotika, robotická stavebnice, základní škola, algoritmizace, programování, LEGO Mindstorms EV3.

*Autor pro korespondenci: batko@kvd.zcu.cz

\section{1 Úvod}

Následující příspěvek se zabývá využitím robotické stavebnice LEGO Mindstorms EV3 jako pomůcky pro výuku algoritmizace a programování na základních školách. V současném RVP, platném od března 2017 s platným opatřením z června téhož roku, zmínku o robotice nenacházíme (MŠMT, 2017). Dle národního ústavu pro vzdělávání je však zapotř̌ebí rámcový vzdělávací program průběžně revidovat, což dokládá například zkušenostmi ze škol, které reflektují, že je potřeba RVP upravit, nebo změnou zákonů (NÚV, 2020). Postup revizí pak probíhá ve spolupráci s připravovanou strategií vzdělávací politiky ČR do roku 2030+ (NÚV, 2020). Strategie vzdělávací politiky ČR do roku 2030+ plynule navazuje na Strategii vzdělávací politiky do roku 2020 (NÚV, 2020). Na základním dokumentu začal pracovat osmičlenný tým expertů pod vedení prof. Arnošta Veselého. Úkolem této skupiny bylo vytvořit dokument, který stanoví cíle, hlavní směry a způsoby, jak cílů dosáhnout. $Z$ tohoto dokumentu pak vzniká vlastní strategie. Předseda skupiny prof. Arnošt Veselý pak ve svém shrnutí dosavadní práce doslova uvádí: "Často říkáme, že tvoříme, jakýsi „věšák" (nebo „kostru“), na který budou dále „zavěšována“ již konkrétní opatření. Samotnou strategii vzdělávací politiky, včetně implementačního plánu, by již mělo vytváret primárně MŠMT a externí expertní skupina by zde měla plnit především oponentní a konzultační roli (Veselý, 2019).“

Samotná strategie, která vznikla na základě stanovených hlavních směrů už s robotikou v jistých oborech počítá. Jedná se však o odborné vzdělávání. Cílem jsou tedy střední, vyšší odborné a vysoké školy (Fryč et al., 2020). V rámci stanoveného strategického cíle "Strategický cíl 1: Zaměřit vzdělávání více na získávání kompetencí potřebných pro aktivní občanský, profesní i osobní život” je však apel na podporu a rozvoj informatického myšlení (Fryč et al., 2020). Na webu iMysleni.cz pak nalezneme učebnice, které jsou připraveny pro rozvoj informatického myšlení a odpovídají inovovaným RVP. 
Zapojením robotické stavebnice do výuky se zabývají také v zahraničí. V člán$\mathrm{ku}$ „Identification of the Students Learning Process During Education Robotics Activities“se autoři zabývají tím, jaký vliv má výuka s využitím robotické stavebnice na učení žáků. Žáci mají za úkol splnit připravené aktivity, kdy autoři považují za klíčové využívání senzorů, které robot nabízí. Výzkumníci zároveň zkoumají chování a přístup žáků, při práci s grafickým programovacím prostředím LEGO Mindstorms EV3. (Scaradozzi et al., 2020)

Afari a Khine (2017, s. 437-442) se zabývali tím, zda má použití robotické stavebnice vliv na rozvoj kritického myšlení žáků, schopnosti řešení problémů, spolupráce a schopnosti vymýšlet inovativní postupy řešení. Pro svou práci využili stavebnici LEGO Mindstorms EV3, která je dle jejich slov dobře připravena pro využití ve výuce. Svá tvrzení dokládají tím, že je stavebnice poměrně všestranná. Umožňuje totiž vytvářet nespočet konstrukcí, které jsou bud’ připraveny př́mo od firmy LEGO, nebo jsou sdíleny komunitou. Stavebnice navíc nevyžaduje pro postavení robota žádné speciální nástroje, ani odborné znalosti. Dále je dle autorů stavebnice pro žáky jednoduše atraktivní. V neposlední řadě je výhodou stavebnice fakt, že obsahuje veškeré nezbytné komponenty pro tvorbu vlastních robotů. Chování robotů pak může být řízeno pomocí sensorů a motorů, které jsou připojeny k programovatelné řídící jednotce. Závěrem autorů je, že díky představeným výhodám a možnostem robotické stavebnice LEGO je evidentní, že bude pozitivně působit na rozvoj kritického myšlení a schopnosti řešení problémů.

Cílem tohoto př́spěvku je představit výsledky výzkumu provedeného v roce 2018. Jeho cílem bylo zjistit, jak si žáci základní školy počínají při řešení úloh ze školní robotiky, které zahrnují prvky abstrakce a jejichž obtížnost v průběhu řešení stoupá. $V$ článku představíme pouze část dosažených zjištění. Zaměříme se na to, jak byli žáci schopni řešit své první úlohy v programovacím prostředí LEGO Mindstorms EV3 bez předchozích zkušeností. Popíšeme, jaké se u nich objevovaly charakteristické návyky a také jakých nejčastěǰ̌ích chyb se při řešení úvodních seznamovacích úloh dopouštěli. Zaměříme se také na genderové rozdíly. Př́spěvek navazuje na článek s názvem „Robotic Kit LEGO as a Means of Getting Acquainted with Educational Robotics" publikovaný v roce 2019 na konferenci INTED 2019 (Batko et al., 2019). V článku byly publikovány prvotní výsledky výzkumu, které nyní doplňujeme o další a podrobnější zjištění. 


\section{Metodologie výzkumu}

Při návrhu výzkumu bylo potřeba zohlednit a zvážit několik hledisek. Cílovou skupinu jsme volili na základě povahy zamýšleného testování. S ní souvisela také připravovaná sada testovacích úloh. Značný důraz byl kladen na co nejpodrobnější zdokumentování počínání žáků během řešení, čemuž bylo uzpưsobeno dispoziční řešení testování.

\subsection{Volba cílové skupiny}

Pro volbu cílové skupiny byla hledána opora v odborných publikacích zaměřených na vývoj dítěte, vývojovou psychologii a psychologii dítěte. Záměrem bylo zahrnout do připravované sady úloh prvky abstrakce. Pro řešení měl být použit pojízdný robot, který se bude pohybovat v prostoru. Žáci by si proto měli být schopní dokázat představit, kudy jeho cesta musí vést, na jakou stranu musí zatočit a o kolik stupňů, aby úspěšně splnili zadaný úkol. Bylo se proto potřeba zaměřit na skupinu žáků, která se nachází ideálně v období rozvoje abstraktního myšlení.

Vycházeli jsme především z poznatků Piageta, který rozdělil kognitivní vývoj člověka na čtyři hlavní stádia. Pro potřeby našeho výzkumu jsou zásadní poslední dvě. V rámci stádia konkrétních operací se již žáci při myšlení přestávají opírat o vlastní zkušenosti a uvažují spíše logicky. Zároveň jsou schopni vyvozovat závěry na základě posouzení více hledisek a uvažovat logicky. Žáci jsou tak schopni zvažovat více aspektů a možností řešení.

Poslední stádium kognitivního vývoje je nazýváno stádiem formálních operací. Charakterizuje je zejména rozvoj abstraktního myšlení, systematického plánování a schopnosti vytváření metodických postupů. Myšlení žáků je systematičtější a má spíše deduktivní charakter. U žáků se zároveň rozvíjí matematické schopnosti a schopnosti řešení problémů. (Thorová, 2015; Piaget \& Inhelder, 2014)

Na začátku stádia formálních operací je žákům mezi 11 a 12 lety. Čačka (2000, s. 121) uvádí, že v tomto věku dochází ke zlepšování myšlenkových operací. Tomuto věku odpovídá zhruba věk žáků 6 . ročníku základní školy. $Z$ toho důvodu jsme si tento ročník zvolili jako naši cílovou skupinu pro realizaci testování. 


\subsection{Volba robotické stavebnice a programovacího prostředí}

Volba robotické stavebnice, ze které bude využívaný model sestaven, vycházela z několika požadavků. Bylo potřeba, aby stavebnice umožňovala sestavit pojízdný model robota, který bude mít dobré jízdní a manévrovací vlastnosti. Všechny úlohy obsažené $\mathrm{v}$ testovací sadě byly totiž zaměřeny na pohyb pojízdného robota v prostoru.

Zároveň jsme chtěli využít produkt, který bude pro žáky poutavý a snadno ovladatelný. Hlavním východiskem pro nás byly výsledky dotazníkového šetření publikované v roce 2017 (Batko, 2017). V něm se ukázalo, že drtivá většina $z$ dotazovaných respondentů využívá ve své výuce produkty společnosti LEGO (LEGO Mindstorms EV3 nebo LEGO Mindstorms NXT). Očekávali jsme také, že pokud zvolíme tuto stavebnici, může být žáky snáze přijata z důvodu předpokládaných zkušeností s jinou dětskou stavebnicí této populární dánské společnosti.

Roboti použití při testování tedy byli sestaveni ze stavebnice LEGO Mindstorms EV3. Konstrukce byla sestavena na základě návodu dodávaného výrobcem. (LEGO, 2020) Provedeny byly některé úpravy směřující primárně k jejímu zjednodušení. Nejednalo se o zásadní úpravy konstrukce, ale byly hlavně odstraněny přebytečné prvky, které nebyly při testování využívány, jako např́klad úchyty pro senzory.

Programovací prostředí jsme volili na základě věku testovaných žáků a jejich předpokládaných zkušeností. Očekávali jsme, že většina z nich nebude mít žádné nebo velice slabé zkušenosti s programováním. $Z$ toho důvodu jsme zavrhli volbu prostředí, ve kterém by se program vytvářel zápisem programového kódu, a zvolili jsme blokově orientované programovací prostředí, kde je kód vytvářen logickým propojováním a uspořádáním bloků. S ohledem na zvolenou robotickou stavebnici bylo využito programovací prostředí LEGO Mindstorms EV3.

\subsection{Testovací sada úloh}

Testovacím nástrojem pro realizaci výzkumu byla sada vlastních úloh z oblasti školní robotiky. Hlavním kritériem výběru úloh bylo zařazení pouze úkolů, u kterých řešení souviselo s pohybem robota v prostoru s využitím motorů. Díky tomu došlo k zúžení řešené problematiky a žáci nemuseli při programování využívat senzory, což by vyžadovalo vyšší úroveň jejich vstupních znalostí. 
Naším cílem bylo zahrnout do připravovaných úloh několik základních programovacích prvků. V úlohách se tak objevují tři typy úloh obsahující následující programové prvky:

1) Práce s parametry - žákům byly k řešení předloženy úlohy, pro jejichž vyřešení je nutné měnit rychlost pohybu robota, ovlivňovat délku jeho pohybu a směr.

2) Opakování - úlohy, ve kterých je vhodné pro snadnější a efektivnější vyřešení použít opakování.

3) Podminěné rozhodování - úlohy využívající podmíněné výrazy.

Úlohy na sebe postupně navazovaly a jejich obtížnost se zvyšovala. Přesto byl dưraz kladen na to, aby se ve všech krocích (vyjma některých výjimek) jednalo o krátké programové konstrukty. Při návrhu jsme vycházeli jednak ze zjištění získaných dotazníkovým šetřením (Batko, 2017), ve kterém učitelé uváděli, že ve výuce využívají nejčastěji krátké, na sebe navazující úlohy a také ze zkušeností s dostupnými kurzy pro výuku algoritmizace a programování, např. projekt Code. org s názvem Hodina kódu (Code.org, 2020).

Vytvořená sada úloh obsahovala celkem 15 úkolů. Úloha vždy obsahovala krátké textové zadání, které doplnil ilustrační obrázek. Na ploše měli žáci k dispozici bloky potřebné $\mathrm{k}$ jejímu vyřešení. Jejich počet záměrně neodpovídal počtu potřebnému pro vyřešení úlohy. Bloků bylo zpravidla mnohem více. Na ploše ovšem žáci našli ty, které $\mathrm{k}$ vyřešení úlohy potřebovali. Umístění bloků na plochu žáky oprostilo od nutnosti hledat vhodné bloky v jejich galerii.

Pilotní ověřování testovací sady úloh proběhlo v březnu a dubnu 2018. Ověřována byla zejména struktura a návaznost př́ikladů s cílem odhalit problémy ve znění zadání a identifikovat problematické úlohy.

Pilotáž byla provedena ve dvou fázích na celkem 4 žácích rozdílných studijních výsledků a zájmů. Jejich věk se pohyboval mezi 11 a 12 lety. V první fázi bylo odhaleno několik nedostatků a problémů v zadáních úloh. Některé úlohy byly nahrazeny jinými nebo posunuty na jinou pozici. V průběhu pilotáže byl simulován kompletní průběh zamýšleného testování včetně video a audio záznamu a zjištování vstupních a výstupních informací od žáků.

Z pilotáže vzešla finální sada 15 úloh, jejichž zadání je znázorněno v tabulce 1. 
Tab. č. 1: Zadání všech úloh obsažených v testovací sadě.

\begin{tabular}{|c|c|c|}
\hline $\begin{array}{l}\text { Pořadové } \\
\text { čislo úlohy }\end{array}$ & Ilustrační obrázek & Zadání a cíle úlohy \\
\hline 1 & ब违। & $\begin{array}{l}\text { Zadání: } \\
\text { Zařid', aby robot jel } 4 \text { vteřiny vpřed a poté zastavil. }\end{array}$ \\
\hline 2 & n a rychlost $80 \%$ & $\begin{array}{l}\text { Zadání: } \\
\text { Zařid,' aby robot jel vpřed po dobu } 5 \text { vteřin rychlostí } 80 \% \text {. }\end{array}$ \\
\hline 3 & 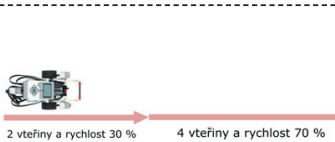 & $\begin{array}{l}\text { Zadání: } \\
\text { Zařid', aby robot jel vpřed nejprve } 2 \text { vteřiny rychlostí } 30 \% \text {, } \\
\text { poté zrychlil a } 4 \text { vteřin jel rychlostí } 70 \% \text {. }\end{array}$ \\
\hline 4 & 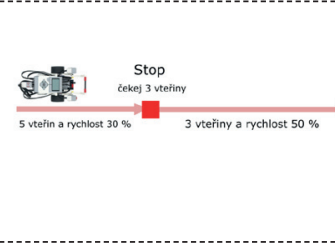 & $\begin{array}{l}\text { Zadání: } \\
\text { Zařid,' aby jel robot nejprve } 5 \text { vteřin vpřed rychlostí } 30 \% \text {, poté } \\
\text { na } 3 \text { vteřiny zastavil a následně } 3 \text { vteřiny pokračoval vpřed } \\
\text { rychlostí } 50 \% \text {. } \\
\text { Použij bloky umístěné na ploše. } \\
\text { Tip pro řešení: Blok Wait oddálí vykonání další činnosti o zada- } \\
\text { ný počet vteřin. }\end{array}$ \\
\hline 5 & 4 v veteriny & $\begin{array}{l}\text { Zadání: } \\
\text { Zařid', aby jel robot } 4 \text { vteřiny vpřed, poté se otočil } 090^{\circ} \\
\text { doprava a pokračoval opět } 4 \text { vteřiny vpřed. }\end{array}$ \\
\hline 6 & Cil & $\begin{array}{l}\text { Zadání: } \\
\text { Zajisti, aby robot svým pohybem vykreslil čtverec o libovolné } \\
\text { délce strany. }\end{array}$ \\
\hline
\end{tabular}




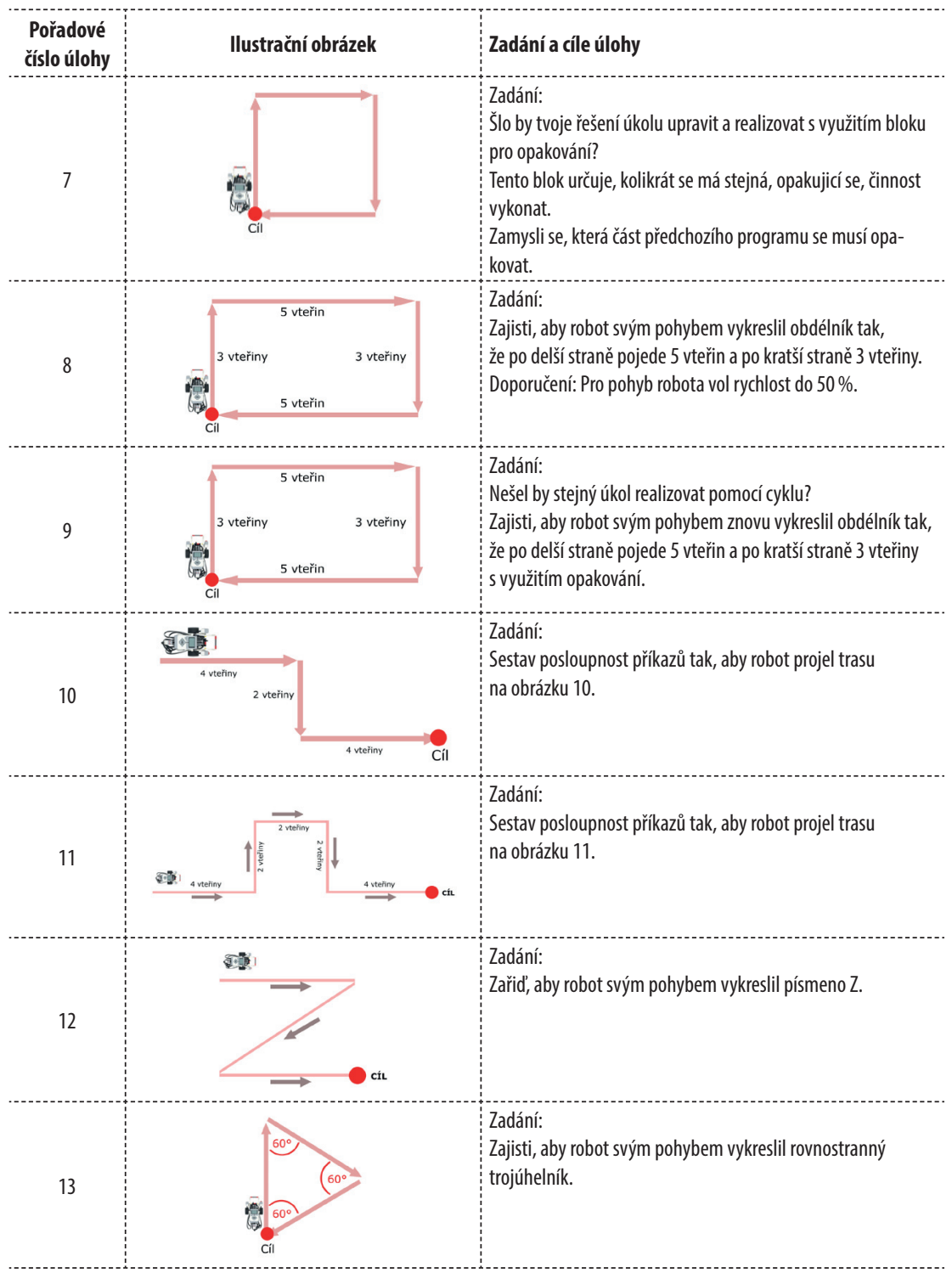




\begin{tabular}{|c|c|c|}
\hline $\begin{array}{l}\text { Pořadové } \\
\text { čislo úlohy }\end{array}$ & Ilustrační obrázek & Zadání a cíle úlohy \\
\hline 14 & 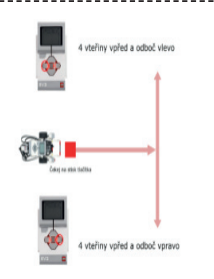 & $\begin{array}{l}\text { Zadání: } \\
\text { Zajisti, aby robot: } \\
\text { pokud stiskneš levé tlačítko řídíí jednotky, jel } 4 \text { vteřiny vpřed } \\
\text { a pak odbočil doleva, } \\
\text { pokud stiskneš pravé tlačítko řídíí jednotky, jel } 4 \text { vteřiny } \\
\text { vpřed a pak odbočil doprava. }\end{array}$ \\
\hline 15 & 3ntimy vieled azstar & $\begin{array}{l}\text { Zadání: } \\
\text { Vytvoř program, po jehož spuštění bude robot čekat na stisk } \\
\text { tlačítka na řídíí jednotce. Pokud stiskneme tlačítko vpřed, } \\
\text { rozjede se na } 3 \text { vteřiny kupředu, pokud stiskneme tlačítko } \\
\text { vzad, bude } 3 \text { vteřiny couvat. }\end{array}$ \\
\hline
\end{tabular}

\subsection{Dispoziční řešení testování}

Testování každého žáka se skládalo z několika částí. Důraz byl kladen zejména na co nejpodrobnější záznam jejich počínání. Jednalo se o kombinaci př́mého pozorování a pořizování videozáznamu, který byl posléze analyzován. Pro dodržení platné legislativy jsme před začátkem výzkumu požádali zákonné zástupce žáků o vyjádření souhlasu s účastí žáka ve studii. Níže jsou uvedeny jednotlivé fáze testování.

\section{1) Audio a video záznam}

V průběhu testování byl pořizován záznam dvěma různými způsoby. Samotná práce žáků byla zaznamenávána na pracovním notebooku pomocí aplikace Open Broadcaster Software. Použití této aplikace nám umožnilo zaznamenávat pracovní plochu počítače a zároveň záznam z webkamery. Zachytili jsme tak pracovní postup žáka a kompletní dění na ploše počítače a zároveň reakce žáka v průběhu řešení, jeho emoce a psychické rozpoložení. Součástí výsledného videa je také audiozáznam, ze kterého bylo možné vyhodnotit dotazy a komentáře žáka.

V místnosti byla zároveň umístěna statická kamera, která snímala místo určené pro testování vytvořených programů. Ta nám dala k dispozici náhled na testování 
z jiného úhlu pohledu a umožnila tak odhalit problémy, které nebyly zachyceny při př́mém pozorování nebo ze záznamu pořizovaného na počítači.

\section{2) Vstupní dotazník}

Na začátku testování byl žákům předložen vstupní dotazník. Jeho cílem bylo získat základní charakteristické informace o daném jedinci. Jednalo se zejména o věk, předchozí zkušenosti s robotikou, zájmy žáka, vysněné budoucí povolání a známky na posledním vysvědčení. Do vstupního dotazníku zároveň výzkumník zaznamenával, jaké bylo psychické rozpoložení žáka na začátku testování. V případě potřeby mohl uvést i další poznámky.

Pro pozdější vyhodnocení získaných dat bylo důležité zjistit, zda se již žáci někdy setkali s programováním robota či robotické stavebnice. Testování sice bylo realizováno s žáky, kteří se s robotikou nikdy nesetkali v rámci výuky, ale dalo se očekávat, že některý z žáků může navštěvovat kroužek robotiky, jiné volnočasové aktivity nebo mít doma vlastního robota.

\section{3) Úvodní instruktáž}

V rámci úvodní instruktáže se žáci seznámili zejména s využívanou robotickou stavebnicí a s programovacím prostředím. Při úvodní instruktáži byla použita kombinace slovních metod (vysvětlování a rozhovor) a metod názorně demonstračních. Představen byl například postup vytváření programu, způsob propojování bloků a nastavení jejich parametrů, základní funkce programovacího prostředí potřebné pro testování nebo také způsob nahrání programu do řídící jednotky.

\section{4) Hlavní část testování}

Průběh testování měl jasně stanovená pravidla představená během úvodní instruktáže. Žáci pracovali samostatně a výzkumník zde plnil pouze roli pozorovatele a zaznamenával si informace do záznamového archu. Informace se týkaly zejména žákovy úspěšnosti při řešení úloh, emocí projevovaných během testování, př́ipadně nutných zásahů výzkumníka do řešení (např. upozornění na chybné řešení, drobná nápověda při značných obtížích znemožňujících pokračování).

\section{5) Závěrečný dotazník}

Závěrečné dotazování mělo formu krátkého rozhovoru. Jednalo se o subjektivní zhodnocení průběhu testování z pohledu žáků. Žáci zde zhodnotili, jak se jim při 
testování dařilo, které úlohy pro ně byly nejsnáze a které nejhůře řešitelné a jaký dojem v nich testování zanechalo.

\subsection{Cílová skupina testování}

Pro realizaci testování byla navázána spolupráce s jednou základní školou v Plzni. Její název záměrně anonymizujeme. Jedná se o městskou školu, kterou navštěvuje zhruba 650 žáků a výuka zde probíhá na obou stupních vzdělávání. Hlavní filozofií školy je budovat podnětné a tvưrčí prostředí, která bude stimulovat nadané žáky a vytvářet povzbuzující podpůrné prostřední pro žáky méně nadané.

$\mathrm{Na}$ škole je od 6. ročníku zařazen př́mo do výuky předmět robotika s časovou dotací 1 hodinu týdně. V 7. ročníku se skupina zájemců připravuje na účast v robotických soutěžích. Pro výuku robotiky je ve škole vytvořena speciální učebna. Využita byla také pro potřeby testování.

Testování proběhlo v rámci výuky předmětu robotika. Zapojeny do něj byly dvě třídy žáků 6. ročníku. Probíhalo postupně, vždy po menší skupince o maximálně dvou žácích. Celkem prošlo testováním 42 žáků. Ve výsledcích jsou zpracovány výsledky pouze 39 z nich. Některé výsledky musely být z vyhodnocení vyřazeny $z$ důvodu nevyhovujícího video nebo audio záznamu a $v$ jednom př́padě kvưli dřívějšímu odchodu žákyně z výuky.

Představené výsledky jsou získány vyhodnocením dat od 39 žáků - 25 chlapců a 14 dívek. Jejich věk se pohyboval mezi 11 a 12,5 lety. Pouze jeden z žáků na počátku testování uvedl, že vlastní programovatelného robota. Další žák se s robotem setkal pouze jednou u kamaráda a dva krátce na př́městském táboře. Jeden žák v době testování začal docházet na kroužek robotiky, který byl ovšem teprve na svém začátku. Všichni ostatní žáci shodně uvedli, že nemají s robotikou absolutně žádné zkušenosti.

\section{Výsledky výzkumu}

V tomto př́spěvku se zaměříme pouze na část výsledků získaných v průběhu výzkumu. Představíme, jak se žáci dokázali na počátku testování adaptovat na blokové programování v programovacím prostředí LEGO Mindstorms EV3, se kterým neměli žádné dřívějši zkušenosti, pouze s ním byli seznámeni v průběhu úvodní instruktáže. Popíšeme charakteristický způsob chování žáků při řešení úvodních 
úloh, dobu jejich řešení a návyky, které si při prvotním seznámení s prostředím vybudovali.

\subsection{Prvotní seznámení s programovacím prostředím}

Nejprve představíme, jak se žáci dokázali při řešení úvodních 4 úloh v prostředí LEGO Mindstorms EV3 adaptovat. Tyto úlohy byly zaměřeny pouze na pohyb robota vpřed. Při jejich řešení museli žáci volit správné pořadí a režim programových bloků a také nastavit jejich vhodné parametry v souladu se zadáním. Poukážeme také na to, jak se na jejich chování a úspěšnosti projevila první obtížnější úloha, která zaváděla nový prvek, kterým bylo zatáčení robota (úloha číslo 5).

Kompletní informace týkající se ovládání prostředí, způsobu vytváření programu, jeho úprav, nahrání do řídící jednotky a spuštění získali žáci v průběhu úvodní instruktáže. V průběhu vysvětlování se u nich stř́idaly různé emoce (např. očekávání, nadšení, nervozita nebo sebepodceňování).

Při analýze videozáznamů bylo nejprve ověrováno, zda byla úvodní instruktáž pro žáky dostačující pro bezproblémovou adaptaci v programovacím prostředí. Výsledky naznačují, že informace byly dostatečné. Nebylo zjištěno, že by některý z žáků nezačal okamžitě pracovat a zkoumat dostupné programové bloky. Pokud se žáci na něco dotazovali, otázky nebyly směřovány k ovládání programovacího prostředí, ale spíše k nabízeným programovým blokům a jejich režimům. Jen jeden žák měl s řešením úvodní úlohy značné potíže a můžeme tak u něj mluvit o nepochopení principu programování. Při řešení úlohy nahodile zkoušel všechny režimy programových bloků, volil je nesprávně a po spuštění programu byl sám překvapen z chování robota a netušil, jak jej dosáhl. Celkem 19 žáků nevykazovalo na začátku testování žádné znatelnější problémy s řešením úvodní úlohy.

U dalších 18 žáků docházelo nejčastěji k problémům, které souvisely s neznalostí parametrů programových bloků. Výsledkem bylo to, že žáci často měnili parametry bloků, jejich pořadí a výsledné programy opakovaně testovali. Řada žáků nedokázala odlišit blok pro ovládání jednoho motoru od bloku pro ovládání dvou motorů, a to i přesto, že na to byli při instruktáži opakovaně upozorněni. Díky tomu docházelo k nežádoucímu chování robota. Výrazné problémy, které téměř znemožnily řešení úlohy, jsme odhalili pouze u jednoho žáka. 


\subsection{Doba řešení úvodních úloh}

Čas řešení úvodních úloh byl ovlivněn zejména aktuálně získanými zkušenostmi, psychickým rozpoložením žáků a pochopením principu programování. Na počátku testování ještě nebyly výsledky žáků ovlivněny únavou z dlouhého průběhu. V dalších fázích testování se na časech řešení některých úloh mohla projevit také nutnost realizovat více programových kroků.

V tabulce 2 je znázorněn nejrychlejší, nejpomalejší a průměrný čas řešení úvodních pěti úloh. $Z$ dosažených výsledků je patrné, že úvodní úloha byla pro žáky podstatně náročnější než následující tři. Průměrný čas se bližil k 6 minutám. Nejpomalejši žák řešil úlohu déle, než 15 minut. Následující tři úlohy vždy dokázal nejrychlejší žák vyřešit zhruba za 1 minutu, $\mathrm{v}$ průměru v čase od 2 do 2,5 minut. Úloha číslo 5 ale zaváděla do programování nový prvek, na který žáci nebyli zatím zvyklí a neuměli si s ním tak rychle poradit. Často hledali vhodný způsob, jak zatáčení zrealizovat, zkoušeli různé režimy programového bloku a svá řešení testovali. Tyto skutečnosti jsou patrné z průměrného času řešení, který přesáhl 12 minut. Žák, který měl s řešením této úlohy největší problémy, potřeboval na její vyřešení a úspěšné otestování více než 45 minut. Výsledky tedy ukazují, že po osvojení základní práce s režimy a parametry programových bloků bylo zatáčení poměrně zásadní překážkou a změnou.

Tab. č. 2: Nejrychlejší, nejpomalejší a průměrný čas (minuty a sekundy) řešení úvodních pěti úloh zaznamenaný u testovaných žáků.

\begin{tabular}{c|c|c|c} 
& Nejrychlejší čas & Nejpomalejší čas & Prüměrný čas \\
\hline Úloha 1 & $01: 25$ & $16: 55$ & $05: 55$ \\
Úloha 2 & $00: 45$ & $05: 45$ & $02: 01$ \\
Úloha 3 & $01: 00$ & $08: 35$ & $02: 26$ \\
Úloha 4 & $01: 05$ & $07: 50$ & $02: 36$ \\
Úloha 5 & $01: 25$ & $45: 55$ & $12: 25$
\end{tabular}

Tabulka 3 znázorňuje rozdíly v časech řešení chlapců a dívek. Chlapci byli ve všech př́padech, až na některé individuální výkony jednotlivců (velice rychlí nebo problematičtí žáci), rychlejši ř řšitelé. Po podrobném porovnání obou skupin bylo ale možné konstatovat, že chlapci dosahovali v rámci úvodních úloh rychlejších časů řešení než dívky. Tento trend přetrval i u zlomové úlohy číslo 5 . Zde je z dosaže- 
ných časů také zřejmé, že chlapci dosahovali nižších časů řešení. Výjimkou byla dívka, která úlohu vyřešila nejrychleji ze všech testovaných žáků.

Tab. č. 3: Nejrychlejší, nejpomalejší a průměrný čas (minuty a sekundy) řešení úvodních pěti úloh všech testovaných chlapců a dívek.

\begin{tabular}{|c|c|c|c|c|c|c|}
\hline & \multicolumn{2}{|c|}{ Nejrychlejš́ čas } & \multicolumn{2}{|c|}{ Nejpomalejší čas } & \multicolumn{2}{|c|}{ Průměrný čas } \\
\hline & chlapci & dívky & chlapci & dívky & chlapci & dívky \\
\hline Úloha 1 & 01:25 & 01:40 & 11:05 & $16: 55$ & $05: 22$ & $06: 54$ \\
\hline Úloha 2 & $00: 45$ & 01:15 & 05:45 & 05:40 & 01:55 & $02: 12$ \\
\hline Úloha 3 & 01:00 & 01:40 & 06:10 & 08:35 & 01:41 & 03:46 \\
\hline Úloha 4 & 01:05 & 01:30 & 06:30 & 07:50 & $02: 20$ & 03:03 \\
\hline Úloha 5 & $03: 40$ & $01: 25$ & $28: 15$ & $45: 55$ & $10: 05$ & $16: 36$ \\
\hline
\end{tabular}

U 14 žáků z 39 se opakoval stejný model řešení úvodních čtyř úloh, které se zaměřovaly na práci s parametry a režimy programového bloku. Nejvíce času žákům zabralo řešení první úlohy. Dá se př̌edpokládat, že důvodem byl zejména nedostatek zkušeností. Po jejich získání a úspěšném vyřešení úvodní úlohy se čas řešení následující úlohy významně zkrátil. Navazující úlohy číslo 3 a 4 pracují s dalšími bloky a novými parametry, které kombinují. Řešení každé další úlohy tedy bylo pro žáky časově o něco málo náročné.

Popsaný průběh považujeme za základní vzorec běžného řešení úvodních čtyř testových úloh. U ostatních žáků registrujeme řadu jiných vzorců chování. Jedná se vždy ale o chování zaznamenané jen u malého počtu žáků a často je způsobené problémy při řešení některé $\mathrm{z}$ úloh. Pokud se naopak doba řešení snižuje, znamená to, že ačkoliv je úloha náročnější, žák je schopen jejího vyřešení velmi rychle. Příčinou je zpravidla použití již dříve naučeného postupu nebo využití části kódu z předchozí úlohy.

\subsection{Testování správnosti řešení}

Při řešení jednotlivých úloh žáci ověřovali správnost řešení nahráním programu do řídící jednotky a jeho spuštěním na vyhrazeném místě před statickou kamerou. Při vyhodnocení videozáznamu bylo následně zjištováno, kolikrát museli žáci program otestovat, než došli ke správnému řešení v souladu se zadáním. Žáci testovali své řešení budto průběžně (vytvářeli program po malých částech) nebo až na konci (po vytvoření celého programu). 
V tabulce 4 představujeme průměrný, minimální a maximální počet pokusů potřebných k úspěšnému otestování programu u úvodních pěti úloh. U úvodních čtyř úloh žáci potřebovali k otestování v průměru 2-3 pokusy. Často navrhli kompletní řešení programu, ale po jeho otestování zjistili, že program obsahuje chybu. Museli ji tedy opravit a program znovu otestovat. Většina žáků potřebovala $\mathrm{k}$ otestování těchto úloh maximálně 5 pokusů. Žák, který měl u úvodní úlohy největší potíže, musel svůj program otestovat dokonce 16x, než došel ke správnému řešení. Každou $z$ úvodních úloh ale zároveň dokázal některý žák vyřešit hned na první pokus.

Výrazný nárůst pokusů testování nastal při řešení 5 . úlohy. $\mathrm{V}$ průměru jich zde žáci potřebovali na úspěšné vyřešení nejvíce ze všech 15 testovacích úloh. Důvodem bylo zejména hledání správné míry zatočení robota a s tím související postupné testování navrženého řešení.

Tab. č. 4: Minimální, maximální a průměrný počet pokusů potřebných k úspěšnému otestování programu zaznamenaný u úvodních pěti úloh.

\begin{tabular}{c:c:c:c}
\hline Testování spránnosti & Minimální počet pokusů & Maximální počet pokusů & Průměrný počet pokusů \\
\hdashline \hdashline Úloha 1 & 1 & 16 & 3 \\
\hline Úloha 2 & 1 & 6 & 2 \\
Úloha 3 & 1 & 5 & 1 \\
Úloha 4 & 1 & 5 & 2 \\
Úloha 5 & 1 & 36 & 11 \\
\hdashline & 1 & &
\end{tabular}

\subsection{Nejčastější chyby při řešení testovacích úloh}

V průběhu testování, ale také při vyhodnocení videozáznamů jsme odhalili některé charakteristické chyby, které se při práci žáků objevovaly. První z chyb jsme odhalili zejména u úvodních úloh. Později se již objevovala velice zř́ídka. Jednalo se o přidávání nadbytečných bloků do programu. Žáci si často neuvědomovali, z kolika programových bloků se musí výsledný program skládat. Proto zkoušeli do programu přidávat další bloky a doufali, že tím dokážou problém vyřešit. Místo toho ale robot vykonával další, nadbytečné pohyby, které si řada žáků nedokázala odůvodnit. Nejčastěji k tomuto jevu docházelo u první úlohy, ve které se žáci s principem programování teprve seznamovali. $V$ dalších úlohách tento jev postupně vymizel a pokud se objevil, dá se předpokládat, že se jednalo spíše 
o nepozornost. Konkrétní údaje jsou obsaženy v tabulce 5 . Z ní je patrné, že mnohem častější sklony k přidávání nadbytečných bloků měli chlapci. Dívky zpravidla postupovaly při řešení úloh systematicky a pomaleji, díky čemuž pravděpodobně nedocházelo k této chybě z nepozornosti.

Tab. č. 5: Četnost přidávání nadbytečných programových bloků u úvodních úloh (chlapci a dívky).

\begin{tabular}{c|c|c}
\hline Přidávání nadbytečných bloků & Chlapci & Dívky \\
\hline Úloha 1 & 13 & 4 \\
Úloha 2 & 5 & 1 \\
Úloha 3 & 2 & 1 \\
Úloha 4 & 2 & 1 \\
Úloha 5 & 3 & 1
\end{tabular}

Další velice častou chybou oddalující úspěšné otestování programu, byly chybně nastavené porty řídící jednotky. Žáci byli na začátku testování upozorněni, že si musí zkontrolovat, zda programově ovládají motor, který mají skutečně připojený k řídící jednotce. Pro snazší rozlišení byly motory připojeny k portům řídící jednotky označenými písmeny A a D.

Stejně jako v přechozím př́padě s přidáváním nadbytečných bloků chybovali také u nastavování portů častěji chlapci. Konkrétní počet případů v úvodních pěti úlohách je uveden v tabulce 6 . Chybovost stoupala zejména u úloh, které $\mathrm{k}$ úspěšnému vyřešení vyžadovaly realizaci většího počtu programových kroků.

Tab. č. 6: Četnost chybně nastavených portů v programu (chlapci a dívky).

\begin{tabular}{c:c|c}
\hline Chybně nastavené porty & Chlapci & Dívky \\
\hline Úloha 1 & 4 & 3 \\
Úloha 2 & 7 & 1 \\
Úloha 3 & 7 & 1 \\
Úloha 4 & 13 & 4 \\
Úloha 5 & 11 & 5
\end{tabular}

\subsection{Zatáčení robota}

V předchozí části jsme kromě počínání žáků při řešení úvodních 4 úloh prezentovali také výsledky, kterých dosahovali při řešení prvního z náročnějších úkoli̊, 
který obsahoval zásadní změnu v chování robota - zatáčení. Předchozí 4 úlohy byly zaměřeny na práci s parametry a režimy programových bloků a robot se v nich vždy pohyboval pouze kupředu. Pátá úloha od žáků vyžadovala zásadní změnu v programu a také změnu $v$ jejich myšlení. Zároveň umožňovala více způsobů, jak ji řešit, které jsme podrobně vysledovali a výsledky nyní představíme. Nejprve ovšem popíšeme, jaké jsou základní možnosti realizace zatáčení

\subsubsection{Možnosti zatáčení}

Zatočení robota se dá vyřešit $\mathrm{v}$ zásadě třemi způsoby a sice použitím pouze jednoho motoru, opačným chodem obou motorů, nebo použitím bloku pro zatočení. Všechny tyto řešení mají své výhody a nevýhody, které se odvíjí zejména od situace, $v$ jaké jsou použity.

\section{Použití pouze jednoho motoru}

Zatočení robota je možné realizovat použitím bloku využívající pouze jeden motor. $\mathrm{V}$ takovém př́padě se bude otáčet jen jedno kolo, druhé zůstane stát a robot se nám otočí. Středem otáčení bude v tomto případě stojící kolo. Tento postup bývá pro žáky velmi snadno pochopitelný a žáci metodou "pokus/omyl" naleznou čas, otáčky, nebo počet stupňů nutných k otočení robota o požadovaný úhel. Tato metoda je však závislá na jisté přilnavosti povrchu. Pokud povrch klouže, prokluzuje točící se kolo a robot zatočí pokaždé jinak. Pokud je povrch př́liš přilnavý, stojící kolo, které se musí na místě otočit, se zadrhává a robot začne lehce poskakovat, nebo se v závislosti na kvalitě konstrukce, kolo uvolní. Blok pracující s jedním motorem je na obrázku 1.

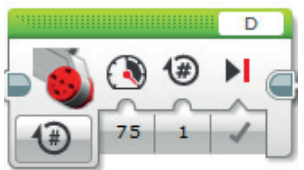

Obr. č. 1: Programový blok pro ovládání jednoho motoru (zdroj: vlastní).

\section{Použití opačného chodu dvou motorů}

Zatočení robota je možné realizovat tím, že aktivujeme motory na obou kolech $\mathrm{v}$ opačném směru. Tím pádem se nám robot otočí na místě. $\mathrm{V}$ tomto případě se 
střed posunul do středu mezi koly. Tento př́stup je velmi efektivní, protože se robot točí prakticky na jednom bodu, takže neodjíždí nikam mimo trasu, čímž dosahujeme lepší přesnosti pohybu. Zároveň nemáme při této metodě problém s tím, že by stojící kolo poskakovalo při př́lišné adhezi. Metoda může působit na první pohled složitěji, kvưli nutnosti nastavení rychlosti u obou motorů. Blok pracující s dvěma motory je na obrázku 2.

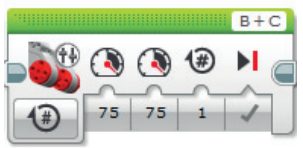

Obr. č. 2: Programový blok pro ovládání dvou motorů (zdroj: vlastní).

\section{Použití bloku pro zatočení}

Může se jevit jako zbytečné zmiňovat se o problému řešení zatočení robota ve chvíli, kdy v programovacím prostředí existuje blok, který je pro to připraven. Blok pro zatočení však funguje na principu rádiusu, který robot opíše. Blok pracuje s různou rychlostí otáčení obou kol ve stejném směru. Tím dochází k zatočení po dané křivce. Výhodou oproti použití bloku s jedním motorem je fakt, že se odvalují obě kola, a tak nedochází k poskakování při silné adhezi. K prokluzu však stále docházet může. Nevýhodou může být, že střed otáčení není ani v jednom z kol, ale je až v prodloužené spojnici jejich středů. Ovládání bloku působí na první pohled velmi intuitivně a pokud fungování bloku chápeme správně, je jeho ovládání velmi snadné pomocí táhla. Je však důležité si uvědomit, že číselná hodnota není úhel, o který by se robot otočil. Blok pro zatočení i s táhlem je na obrázku 3.

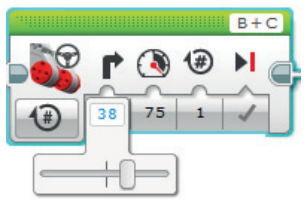

Obr. č. 3: Blok pro ovládání dvou motorů se zvýrazněným parametrem pro zatočení (zdroj: vlastní). 


\subsubsection{Realizace zatáčení robota}

Žáci měli v 5. úloze za úkol zajistit, aby robot zatočil o $90^{\circ}$. Při vyhodnocení výsledků jsme se zaměřili na to, který postup žáci pro zajištění zatáčení zvolili.

Chování žáků při testování odhalilo, že si žáci př́liš neuvědomovali mechanický princip zatočení robota. Rovnou pracovali s programovými bloky a hledali možnosti, jak dosavadní pohyb vpřed upravit. Díky poměrně výrazné grafické podobě parametru Steering (ř́zení) u bloku pro ovládání dvou motorů, velice rychle odhalili, že změnou tohoto parametru mohou v určité míře zatáčení zajistit. Celkem 21 žáků ze 39 řešilo zatáčení tímto způsobem. Blok pro ovládání jednoho motoru použilo pro zatáčení 17 žáků. Většina z nich pracovala s mírou natáčení ve stupních. Zajímavostí je, že jeden žák řešil zatáčení pomocí bloku Move Tank, který slouží primárně k ovládání pásových vozidel. Zatáčení je u něj realizováno nastavením odlišné rychlosti otáčení jednotlivých motorů. Tento žák nepoužil blok Move Tank pouze v této úloze, ale po pozitivní zkušenosti získané v úloze 5 ho používal po celý zbytek testování.

\section{Diskuse výsledků a závěr}

V rámci výzkumné studie byla žákům předložena sada patnácti úloh vlastní konstrukce $\mathrm{z}$ oblasti školní robotiky. Cílem výzkumu bylo zjistit, jak si žáci při řešení těchto úloh, které zahrnují prvky abstrakce, počínají. Všechny úlohy byly postaveny na pohybu robota $v$ prostoru.

$\mathrm{Z}$ výsledků, které byly získávány jednak přímo na místě v rámci přímého pozorování a zároveň prostřednictvím analýzy dvou různých videozáznamů bylo zjištěno, jak se žáci při řešení úloh ze školní robotiky chovají, jak se dokážou na blokové programovací prostředí adaptovat a jaké jsou jejich charakteristické vzorce chování. $V$ tomto příspěvku jsme se zaměřili primárně na chování žáků při řešení úvodních úloh v blokovém programovacím prostředí. Prezentována byla zejména data získaná analýzou řešení úvodních pěti úloh.

Žáci, kteří se testování zúčastnili, se v drtivé většině setkávali úplně poprvé $s$ robotikou a robotickou stavebnicí. Ačkoliv výzkum probíhal v rámci výuky robotiky, po domluvě s vyučujícím se žáci po dobu testování věnovali konstruování a k programování přistoupili až po jeho skončení. Výzkum tak velice dobře napomohl zmapovat, jakým zpơsobem se žáci bez předchozích zkušeností s pro- 
gramovacím prostředím LEGO Mindstorms EV3 a blokovým programováním, seznamují.

Po skončení úvodní instruktáže začali žáci samostatně pracovat. Nezaznamenali jsme žádný prŕípad, kdy by bylo potřeba žákům všechny informace znovu zopakovat. Pokud se na začátku objevily problémy, souvisely s neznalostí nastavení programových bloků a jejich režimů. Důvodem bylo nejspíše postupné seznamování se se zcela novou výukovou pomůckou a způsobem programování, se kterým se nikdy dříve žáci nesetkali. Určitou roli mohla hrát také jazyková bariéra, jelikož programovací prostředí LEGO Mindstorms EV3 je dostupné pouze v anglickém jazyce. Někteří žáci se tak orientovali často pouze na základě ikon u jednotlivých parametrů.

Úspěšnost žáků se zásadně projevovala i v čase řešení úloh. Z úvodních čtyř úloh dosahovali žáci nejdelší doby řešení hned v úvodní úloze. Důvodem byly zejména nulové zkušenosti a postupné seznamování se s prostředím. $Z$ analýzy časů řešení úvodních čtyř úloh jsme zároveň vysledovali běžný vzorec jejich řešení.

Značné rozdíly byly zaznamenány také v časech řešení chlapců a dívek. Chlapci byli podstatně úspěšnější a rychlejší řešitelé. $U$ dívek mnohdy chyběla motivace a nadšení, které se objevovalo primárně u chlapců. Vyšší motivovanost chlapců může souviset s tím, že je jim oblast robotiky bližší. Chlapci zároveň častěji, než dívky uváděli zájem o počítače či jiné technické oblasti.

Podobné výzkumy zaměřené na výkon žáků a jejich chování při práci s robotem nebo robotickou pomůckou probíhají také ve světě. V některých výzkumech se autoři zároveň snažili odhalit odlišnosti v chování a ve výkonnosti chlapců a dívek. Kucuk a Sisman (2020) se zaměřili na postoj studentů střední školy k robotice a oblasti STEM. Výsledky poukazují na vesměs pozitivní postoj studentů $\mathrm{k}$ robotice, ale zároveň na výrazně menší touhu a sebevědomí dívek při výuce robotiky. S těmito projevy jsme se setkávali také v průběhu našeho výzkumu. Při řešení námi navržených úloh se dívky podstatně méně slovně projevovaly, při problémech měly zároveň častější sklony k sebepodceňování. Tyto poznatky ovšem nemůžeme považovat za obecně platné, jelikož se našeho výzkumu zúčastnila pouze omezená skupina žáků. K podobným závěrům jako my dospěli také Sullivan a Bers (2013), kteří se zaměřovali na práci 53 žáků mateřské školy s robotickým programem TangibleK. Autoři předpokládali, že díky nízkému věku žáků by se do výsledků výzkumu nemusely projevit určité genderové stereotypy. Chlapci i dívky by tak mohli dosahovat stejných úspěchů. Přestože chlapci dosahovali u více než poloviny úkolů vyššího průměrného skóre než dívky, pouze velmi 
málo z těchto rozdílů bylo statisticky významných. Chlapci významně vynikali pouze ve dvou zkoumaných oblastech. Z celkového pohledu byli ale chlapci i dívky schopni program úspěšně dokončit. Nemůžeme proto tvrdit, že chlapci dosahují v oblasti edukační robotiky lepších výsledků. Provedené výzkumy ale naznačují, že by dívky mohly vykazovat odlišné chování a mohly by mít také specifické potřeby při výuce robotiky. K podobnému závěru došli také Atmatzidou a Demetriadis (2016), kteří se zaměřovali na rozvoj informatického myšlení pomocí robotické stavebnice u dvou skupin žáků ve věku 15 a 18 let. Z jejich závěrů vyplývá, že dívky v mnoha situacích potřebují více času na trénink, aby dosáhly stejné úrovně dovedností v porovnání s chlapci.

Dívky je tedy při práci s robotickou stavebnicí potřeba více motivovat a vybírat aktivity tak, aby pro ně byly zajímavé a poutavé. Výsledky našeho výzkumu naznačují, že dívky nemají k technice tak vřelý a blízký vztah a že iniciativy, které jsou v současnosti vyvíjeny pro přilákání dívek ke studiu technických oborů, jsou zcela na místě. Př́kladem může být nezisková organizace Czechitas, která si klade za cíl vyrovnat počty žen a můžu v IT oborech. Snaží se zároveň motivovat dívky pro studium nebo práci v IT. Organizace pořádá různé workshopy, kurzy nebo letní tábory k posílení diverzity a konkurenceschopnosti v IT. (Czechitas, 2021)

Žáci se při řešení navržených robotických úloh dopouštěli také některých opakujících se chyb. Mezi hlavní patřilo přidávání nadbytečných bloků do programu a chyby související se špatně nastavenými porty. $V$ obou př́ípadech se chyb častěji dopouštěli chlapci. Důvodem může být odlišný způsob řešení úloh, než tomu bylo u dívek. Chlapci byli velice aktivní, rychlí, díky čemuž mohlo častěji docházet $\mathrm{k}$ chybám $\mathrm{z}$ nepozornosti. Naopak dívky byly při řešení pomalejší, ale o poznání pečlivější.

Na závěr jsme popsali, jaké byly charakteristické zpơsoby zatáčení používané v první úloze, ve které se s ním žáci setkali. Výsledky napověděly, že volbu žáků pravděpodobně značně ovlivnilo grafické provedení bloku pro ovládání dvou motorů. Nejčastěji totiž pro zatáčení využívali parametr pro ovlivnění natáčení robota. Volba pravděpodobně souvisela s tím, že tento parametr měli žáci celou dobu řešení na očích a řada $\mathrm{z}$ nich jeho funkci zkoumala už od první úlohy. Jakmile tedy potřebovali zatáčení použít, okamžitě si na tento parametr vzpomněli.

Představená zjištění poukazují na schopnosti žáků, kteří jsou na počátku rozvoje abstraktního myšlení, řešit úlohy ze školní robotiky bez předchozích zkušeností. Zároveň popisujeme, jaká úskalí žáci při seznamování se s blokovým programováním překonávají, jak jsou při tom úspěšní a jakých chyb se naopak 
nejčastěji dopouštějí. Podobné výzkumy zaměřené na testování žáků s minimálními nebo žádnými zkušenostmi s programováním jsou realizovány také ve světě. Demirkiran a Tansu Hocanin (2021) vyzkoušeli herně orientovanou výuku programování a zjistili, že po jejím průchodu získali žáci v 5. ročníku k základům programování mnohem positivnější vztah. Výzkumem prošlo 63 žáků a jako testovací nástroj byl použit Minecraft Hour of Code. Ačkoliv byli žáci na počátku námi prováděného výzkumu často nervózní a nesmělí, při výstupním dotazování jsme se setkali s výhradně pozitivními reakcemi a nadšením. I přes obtíže při řešení některých úloh tak průběh testování zanechal v žácích pozitivní dojem. Podrobnější výsledky a data získaná analýzou zbývajících úloh budeme publikovat v dalších článcích.

Studie vznikla v přímé souvislosti s řešením grantu Ministerstva školství, mládeže a tělovýchovy České republiky, SGS-2018-019 Výzkum vlivu informačních a komunikačních technologií na vzdělávání.

\section{Literatura}

Afari, E., \& Khine, M. S. (2017). Robotics as an Educational Tool: Impact of Lego Mindstorms. International Journal of Information and Education Technology, 7(6), 437-442. doi:10.18178/ ijiet.2017.7.6.908

Atmatzidou, S., \& Demetriadis, S. (2016). Advancing students' computational thinking skills through educational robotics: A study on age and gender relevant differences. Robotics and Autonomous Systems. Vol. 75, s. 661-670.

Batko, J. (2017). Robotika ve výuce na základních školách v České republice. Výzkumná zpráva v rámci projektu SGS 2016. Západočeská univerzita v Plzni. Dostupné z: https://www.kvd.zcu. cz/cz/dokumenty/Batko_robotika_ve_vyuce_na_ZS_v_CR.pdf.

Batko, J., Rohlíková, L., \& Frank, F. (2019). Robotic Kit LEGO as a Means of Getting Acquainted with Educational Robotics. INTED 2019 Proceedings. $13^{\text {th }}$ International Technology, Education and Development Conference (Valencia, Spain), 3278-3287.

Code.org. (2020). Code.org: Naučte se informatiku. Změňte svět!. Dostupné z: https://code.org/.

Czechitas. (2021). IT je budoucnost. I tvoje. Czechitas [online]. Dostupné z: https://www.czechitas. $\mathrm{cz} / \mathrm{cs} /$

Čačka, O. (2000). Psychologie duševního vývoje dětí a dospívajících s faktory optimalizace. Brno: Doplněk. ISBN 8072390600.

Demirkiran, M. C., \& Tansu Hocanin, F. (2021). An investigation on primary school students' dispositions towards programming with game-based learning. Education and Information Technologies [online]. ISSN 1360-2357. Dostupné z: doi:10.1007/s10639-021-10430-5

Fryč, J., Matušková, Z., Katzová, P., Kovář, K., Beran, J., Vylachová, I., \& Hrdlička, F. (2020). Strategie vzdělávací politiky české republiky do roku 2030+. Praha. Dostupné z: https://www. msmt.cz/file/54104_1_1/ 
Kucuk, S. \& Sisman, B. (2020). Students' attitudes towards robotics and STEM: Differences based on gender and robotics experience. International Journal of Child-Computer Interaction. Vol. 23-24.

LEGO. (2020). LEGO Mindstorms Education EV3: Building Instructions for Core Set Models. LEGO Education [online]. Dostupné z: https:/education.lego.com/en-us/product-resources/ mindstorms-ev3/downloads/building-instructions

Ministerstvo školství, mládeže a tělovýchovy (MŠMT). (2017). Rámcový vzdělávací program pro základní vzdělávání. Dostupné z: https://www.msmt.cz/file/43792_1_1/

Národní ústav pro vzdělávání (NÚV). (2020). Revize RVP. Načteno z Národní ústav pro vzdělávání. Dostupné z: http://www.nuv.cz/t/rrvp

Piaget, J., \& Inhelder, B. (2014). Psychologie ditěte. Přeložil Eva Vyskočilová. Praha: Portál. Klasici. ISBN 9788026206910.

Scaradozzi, D., Cesaretti, L., Screpanti, L., \& Mangina, E. (2020). Identification of the Students Learning Process During Education Robotics Activities. Frontiers in Robotics and AI, 7. doi:10.3389/frobt.2020.00021

Sullivan, A., \& Bers, M. U. (2013) Gender differences in kindergarteners' robotics and programming achievement. International Journal of Technology and Design Education. Vol. 23, s. 691-702.

Thorová, K. (2015). Vývojová psychologie: proměny lidské psychiky od početí po smrt. Praha: Portál. ISBN 9788026207146.

Veselý, A. (29. duben 2019). Příprava Hlavních směrů vzdělávací politiky ČR 2030+: Shrnutí dosavadní práce. Dostupné z: https://drive.google.com/file/d/1W19DEn3RPDU30XH3a6F6z6o YCKvOgwzq/view 